\title{
平面ひずみ状態におけるき裂先端のひずみ分布測定法*
}

\author{
長島 伸夫*1, 早川 正夫*1
}

\section{Strain Distribution Measurement of a Crack Tip under a Plane Strain Condition}

\author{
Nobuo NAGASHIMA* ${ }^{* 1}$ and Masao HAYAKAWA
}

${ }^{* 1}$ National Institute for Materials Science, 1-2-1 Sengen, Tsukuba, Ibaraki 305-0047 Japan

\begin{abstract}
Micro-hardness distribution was measured by using an ultra-micro hardness test at a crack tip under a plane strain condition for a crack propagation test specimen made of a low-carbon austenite stainless steel JIS-SUS316L. Moreover, crystal orientations were analyzed by EBSD for individual crystal grains in the plastic strained area at the crack tip. The conclusions can be summarized as follows. (1) The mean strain in a 500- $\mu \mathrm{m}$ region around the crack tip was supposed with $3 \%$ from the hardness distribution in an ultra-micro hardness test. Therefore, the plasticity strain distribution of the crack tip under a plane strain condition can be visualized based on the ultra-micro hardness and an experience equation of the true strain by measuring the hardness distribution. (2) When the analysis by EBSD increased the step size of the KAM map, the local misorientation increased. On the other hand, the color map of some grain boundary neighborhoods reversed when the step size changed in a GROD map. Therefore, an analysis of KAM is suitable for the local transformation of the crack tip neighborhood. (3) From the results of an EBSD analysis, it became clear that a local heterogeneous transformation occurred in random grain boundaries at the crack tip, and the transformation hardly occurred at the CSL grain boundary of the crack tip.
\end{abstract}

Key Words : SUS316L Stainless Steel, Hardness, EBSD, Plane Strain Condition, Crack Tip, Random Grain Boundary, CSL Grain Boundary

\section{1. 緒言}

鉄鋼材料を用いた大型構造物は経年劣化によりき裂が生じる場合があるが，現在用いられている欠陥検出技術 で検出可能な欠陥（き裂）に対する応力状態は，大型構造物の板厚に対しては平面ひずみであることが多い．例 えば，大型構造物である発電用原子力設備は，発電用原子力設備維持規格 JSME NA1-2007 (1)が定められている. この規格では，静的平面ひずみにおいて最も厳しい值となる破壊勒性值 $\left(K_{I C}\right)$ が適用され，許容される欠陮梁さ は，前提条件として $a=0.0275 t$ 以下である. また，この規格では，検出可能なき裂に対して評価不要欠陥寸法が 定められているが，これらの機器に対して，検出可能な評価不要欠陥寸法は，すべて平面ひずみ条件を満足して いる.さらに実機で問題となる疲労やSCC でき裂成長するき裂先端の応力拡大係数は $K_{I C}$ よりも小さいことから, 実機で検出可能なき裂先端の応力場は，ほぼ平面ひずみ状態である，平面ひずみ状態のき裂先端のひずみ分布の 解析には，計算科学的手法として，き裂先端に生ずる結晶すべりモデルを用い，中央き裂を有する平面ひずみブ ロックのモード I 型のき裂開口を対象として，有限要素法（Finite Element Method; FEM）による解析が試みられ ている(2).さらに分子動力学法(Molecular Dynamics; MD) と FEM の中間であるメゾメカニクス的アプローチの一つ

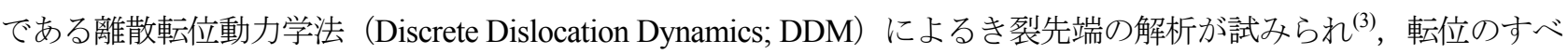
り運動の軌跡と相当塑性ひずみ分布が示されている。一方，実験的手法としては，平面応力状態であれば，表面

\footnotetext{
* 原稿受付 2012 年 7 月 13 日

*1 正員, (独)物質・材料研究機構（†305-0047 茨城県つくば市千現 1-2-1）

E-mail: NAGASHIMA.Nobuo@nims.go.jp
} 
と内部のひずみ分布がほぼ同じであることから，表面ひずみを計測する光弾性法やモアレ法，X 線回折法などに よる計測が報告されているが，内部ひずみを非破壊で直接計測するただ一つの方法である中性子回折法による報 告は見あたらない.しかしながら，いずれの解析においても，多結晶材のき裂先端直近傍の数個程度の結晶粒に おける局所的なひずみ分布を明らかにした事例は見当たらない.

構造物における平面ひずみ状態下でのき裂の発生や進展は, 疲労や応力腐食割れ（SCC）などで問題となって いる. 構造物の多くは多結晶材であることから, き裂先端直近部の数個程度の結晶粒のひずみ状態を把握するこ とは，き裂進展の経路や速度を解析する上で，重要な知見をもたらすと期待される．特に，多結晶材では結晶の 異方性や結晶粒界により，巨視的に均一変形させても，微視的な塑性ひずみの分布は不均一となることが指摘さ れている(4). また, 一つの結晶粒における微視的な塑性ひずみ分布の不均一性は, すべりによる転位が粒界に堆 積することによっても発生する. すべりや粒界に堆積した転位によって, 方位変化が引き起こされている. Ashby は, 変形の不均一性に伴う転位について「幾何学的に必要な転位」(GN 転位 (geometrically necessary dislocation)) と呼び，次のように説明している(5)。転位が粒界に蓄積する機構として，粒内で発生した転位が粒界でその運動 を止められるために粒界に転位の堆積が生ずると理解されることが多いが，「GN 転位」は，これに対して相補的 な解釈，すなわち結晶粒界の近傍に生ずる変形の不均一性に伴って粒界近くに存在しなければならない転位とい う解釈を与えている.

近年, 電子後方散乱解析（EBSD : Electron Backscatter Diffraction）を用いた方位解析が多数なされている(6)-(12). EBSD は走查型電子顕微鏡における電子線解析の一種で, 2 次元的に kikuchi パターンを取得し, その測定点での 結晶方位を示すことができる，さらに，個々の測定点のマッピングにより試料表面の結晶方位や結晶構造を同定 することができる(13). EBSD による方位測定の空間分解能は $50 \mathrm{~nm}$ 程度といわれており ${ }^{(13)}$ ，現在一般的に普及し ている EBSD 装置では材料表面のミリメートルオーダーの領域の方位分布を自動的に取得できる.つまり，マク ロレベルの領域に対してナノメートルオーダーの方位差を調べることができる．先にも述べたように粒界に堆積 した転位は結晶の方位を変化させることから, EBSD 測定では材料の微視的な方位変化が得られる. EBSDによ って得られる方位差の局所分布は, 材料の局所的な変形を評価する有用なパラメータであり ${ }^{(6)}$, 微視組織レベル の塑性ひずみ分布を調べる手がかりになる. EBSD 測定では, 塑性ひずみを表すパラメータとして Kernel Average Misorientation (KAM), Grain Orientation Speard(GOS), Grain Reference Orienrtation Deviation(GROD)などがあるが(7)(9), KAM，GOS，GROD の単位は方位差を示寸角度である. このため, これらの值から直接ひずみ量を求めるこ とはできない。しかし，KAM は隣接する測定点間の方位差を計算し局所的な方位の回転を表すことから，KAM と転位密度の関係に着目した研究が行なわれている ${ }^{(10)}$. また, 局所方位差の平均值と塑性ひずみ量の相関関係か ら塑性ひずみを評価する試みがなされている(11),(12).

一方，硬さと塑性ひずみ量には良い相関関係がある ${ }^{(14)}$. 硬さは，マクロサイズを対象としたビッカース硬さが 標準的に用いられているが，近年，微小領域の材料強度を評価する手法としてナノインデンテーション試験が注 目されている. 我々のグループでは, AFM を基にしたナノインデンテーション試験機を開発し鉄鋼材料について 微小領域の材料評価を行っている(15)-(19). ナノインデンテーション試験では, 圧痕サイズが小さくなると圧子先 端の曲率半径が影響し硬さが上昇するサイズ効果のため, ナノ領域の硬さとマクロ領域のビッカース硬さを直接 比較検討することができなかった，そこで，金属単結晶の電解研磨面を基準試験片とした硬さの換算方法を提案 した ${ }^{(15)}$. この換算方法を用いると，ナノからマクロの硬さを圧痕サイズに関係無く直接比較できる. ナノからメ ゾサイズのような微小硬さでき裂先端の硬さ分布を測定することにより，ナノもしくはメゾ硬さと局所ひずみの 関係を求め, き裂先端のひずみ分布を評価できる可能性がある.

本研究では，平面ひずみ状態におけるき裂先端直近傍の数個程度の結晶粒における局所的なひずみの不均一性 を評価する手法を開発することを目的としている. そこで, 低炭素オーステナイトステンレス鋼 SUS316L の厚板 $\mathrm{CT}$ 試験片を作成し，疲労き裂試験により予き裂を導入し，引張荷重を負荷した．この CT 試験片の中央断面につ いて, 微小硬さ試験機によるき裂先端の硬さ分布測定を行い, 微小硬さによるひずみ分布測定の妥当性を検討し, 測定方法の最適化を図る．併せて，微小硬さと真ひずみの経験式を得る．また，き裂先端に生ずる平面ひずみ状 態の塑性ひずみ域内の個々の結晶の変形を調べるために方位解析を実施する．これらの結果をもとに，平面ひず み状態の塑性ひずみ分布を可視化し, き裂先端近傍の粒界と粒内の局所変形特性について検討できることを示す. 
Table 1 Chemical composition of type 316 Lsteel (mass \%).

\begin{tabular}{|c|c|c|c|c|c|c|c|c|}
\hline $\mathrm{C}$ & $\mathrm{Si}$ & $\mathrm{Mn}$ & $\mathrm{P}$ & $\mathrm{S}$ & $\mathrm{Ni}$ & $\mathrm{Cr}$ & $\mathrm{Mo}$ & $\mathrm{Fe}$ \\
\hline 0.008 & 0.43 & 0.83 & 0.023 & 0.001 & 12.55 & 17.54 & 2.11 & Bal. \\
\hline
\end{tabular}

Table 2 Mechanical properties.

\begin{tabular}{|c|c|c|c|c|}
\hline$\sigma_{0.2}(\mathrm{MPa})$ & $\sigma_{\mathrm{B}}(\mathrm{MPa})$ & $\delta_{\mathrm{T}}(\%)$ & $\phi(\%)$ & $\mathrm{HV}$ \\
\hline 276 & 527 & 66.9 & 87.6 & 134 \\
\hline
\end{tabular}

\section{2. 実験方法}

\section{$2 \cdot 1$ 供試材}

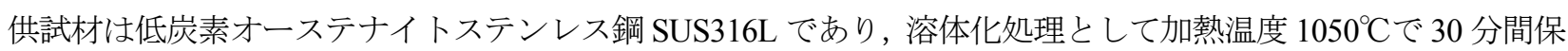
持した後水冷した. 表 1 に化学成分を, 表 2 に機械的性質を示す. また, 真ひずみと硬さの経験式を得るため, 冷間圧延による予ひずみ材（減面率 $R A=10 ， 20 ， 30 ， 40 ， 50 \%$ ）を準備した.

\section{$2 \cdot 2$ き裂進展試験}

き裂進展試験は，室温大気中で $1 \mathrm{kN}$ 容量 の油圧式サーボ試験を用いた。試験片はASTM 規格 E333 に準拠し た 1 インチ CT 試験片（板厚 $25 \mathrm{~mm}$ ）を採用した. 応力比 $R=0.1$ 一定のもと応力拡大係数 $(K)$ を減少させる疲労試 験により予き裂を導入した後, $K=30 \mathrm{MPa} ・ \mathrm{~m}^{1 / 2}$ を目標值にして荷重負荷した. この目標值 $K=30 \mathrm{MPa} ・ \mathrm{~m}^{1 / 2}$ は粒界 型 SCC のき裂進展特性を評価する応力範囲である(1).この CT 試験片を厚さ方向の中央で切断し, それぞれ微小 硬さ測定と方位解析の試料とした.

\section{$2 \cdot 3$ 微小硬さ試験によるき裂先端ひずみ分布}

冷間圧延などで予ひずみを付与した材料では，硬さとひずみ量に良い相関がある(14)．したがって，き裂先端の 硬さ分布を測定することにより，き裂先端のひずみ量を推定することができる．き裂先端の塑性ひずみを調べる ためには,できるだけ細かい間隔で測定することが望まれる. 前報 ${ }^{(18)}$ では SUS316L 鋼の冷間圧延材 (減面率 $R A=10$, 20，30，40，50\%）の圧痕スケールの異なる硬さ試験を実施した．その結果を参考にすると，マイクロビッカー ス硬さ試験機では, $0.49 \mathrm{~N}$ の測定荷重でも形成される圧痕は数十 $\mu \mathrm{m}$ のサイ゙のため, き裂先端の硬さ分布の測 定では測定点数が限られる.さらに, 圧痕を光学顕微鏡で測長するため, この様な微小圧痕では硬さの誤差が生 じる. また，押し込从荷重が $0.5 \mathrm{mN}$ 以下のナノインデンテーション試験機では，減面率が $30 \%$ までは，圧延で 導入されるすべり線の間隔以下の領域の硬さを計測するために無ひずみ材と硬さがほとんど変わらない(18). した がって, ナノ硬度では連続的な塑性ひずみ量の推定には適さない.

一方，ナノインデンテーションとマイクロビッカースの中間サイズである微小硬さ試験機では，低い減面率か ら高い減面率まで，一義的な相関を示しており，き裂先端の硬さ分布の測定に適すると考えられる．まず，微小 硬さ試験機（圧子先端対稜角 $115^{\circ}$ 三角錐ダイヤモンド圧子，100-1000 mN）を用いて, 冷間圧延材の電解研磨面 （研磨によるひずみを除去した）について，押し込み力一押し込み深さ（F-h）曲線を取得した. ビッカース硬さ の換算は, 以下の式 ${ }^{(15)}$ が用いられた. 式(1)を用いることによって, 微小硬さをビッカース硬さに変換することが 可能である.

$$
H v^{*}=\left\{\frac{F}{p(h+q)^{2}}\right\}^{n}
$$

ここで, $H v^{*}$ は換算ビッカース硬さである. また $, p, q$, 及び $n$ は実験的に求められる定数であり, ビッカー 不硬さが既知である $\mathrm{Ni}, \mathrm{Mo}$ 及び $\mathrm{W}$ 単結晶金属より求められる $f-h$ 曲線を基準曲線とし算出される. $p, q$, 及び $n$ はそれぞれ， $0.924 \times 10^{-6}, 238.4 ， 1.18$ である. 
き裂先端に塑性ひずみを導入した $\mathrm{CT}$ 試験片は試験片の厚さ方向の中央で切断した切断面を微小硬さ測定面と した. バフ研磨により鏡面に仕上げた後, 王水（塩酸 $2:$ 硝酸 $1:$ 水 1 ）でエッチングした. 微小硬さ試験機は 押し込み荷重 $250 \mathrm{mN}$ ，測定間隔 $50 \mu \mathrm{m}$ でき裂先端の硬さ分布を測定した.

\section{$2 \cdot 4$ 結晶方位測定}

結晶方位の測定には電界放射型電子銃を装備した走査型電子顕微鏡 (日本電子 JSM-7000F) に設置された EBSD 装置（TSL 社 OIM-Analysis ver.5.3）を用いた． EBSD 測定条件は，加速電圧を $25 \mathrm{kV}$, 試料表面を操作するステッ プサイズを $0.5 \mu \mathrm{m} ， 6$ 角形のピクセル形状でデータを取得した. EBSD 解析に用いた試料は微小硬さ測定に用い たき裂進展試験片の反対側断面を用いた．測定面は，バフ研磨により鏡面に仕上げた後，コロイダルシリカで研 磨した.き裂先端の塑性変形領域と疲労予き裂近傍の繰り返し塑性変形領域との組織を比較するため, き裂先端 を $5 \mu \mathrm{m}$ 含む $200 \times 400 \mu \mathrm{m}$ のき裂先端塑性変形領域と, き裂先端から $2.5 \mathrm{~mm}$ の $250 \times 250 \mu \mathrm{m}$ の領域の繰り返し 塑性変形領域の EBSD 測定を実施した. 粒界はランダム粒界と対応粒界（Coincidence Site Lattice : CSL 粒界）に ついて方位解析し， $5^{\circ}$ 以上の方位差をランダム粒界とした。き裂先端塑性域の塑性変形を定量的に評価するパ ラメータとして, Image Quality(IQ), KAM, GROD の 3 種類を検討した.

IQ は画像処理 Hough 変換後の kikuchi パターンのバンド強度をプロットしたものである. Hough 空間上のピー クはバンドが鮮明なほど強くなる．バンドが鮮明になるということは結晶性が良いことを示し，結晶性を乱す要 因としては試料表面の研磨傷や研磨課程で導入された表面ひずみなどが影響する.

KAM はあるピクセルと隣接する 6 つのピクセル間の方位差の平均を計算し，その值を中心のピクセルの值と する．隣接するピクセル間に粒界が存在した場合には，粒界を認識している傾角（本研究では結晶粒界を方位差 $5^{\circ}$ 以上とした）を指定し，この值を超えた方位差はKAMの計算から除外寸る．KAM の単位は角度であり，こ のマップでは局所的な方位の変化に基づくひずみの分布を表すことができる.

GROD は,一つの結晶内において, その粒の平均方位または KAM が最小值になるピクセルの方位を基準とし， 粒内の他のピクセルがその基準からどれだけの方位差になっているかを示している. 本研究では, KAMが最小 になるピクセルを基準とした．このマップでは粒内の方位の変化の様子がわかる．また，KAM や GROD は測定 ステップサイズが影響するといわれている，そこで本研究ではステップサイズの影響について検討するため， 0.5 $\mu \mathrm{m}$ ステップサイズで測定したピクセルを平均化することで $1 \mu \mathrm{m}$ ステップサイズとして KAM と GROD の解析 も行った.

\section{3. 実験結果}

\section{$3 \cdot 1$ き裂進展試験}

疲労予き裂の下限界応力拡大係数範囲 $\Delta K_{t h}$ の值は $6.3 \mathrm{MPa} \cdot \mathrm{m}^{1 / 2}$ であった．その後， $30 \mathrm{MPa} \cdot \mathrm{m}^{1 / 2}$ の応力拡大係 数を目標に荷重を与えた. 試験後に計測したき裂長さと負荷応力から算出された応力拡大係数は $27 \mathrm{MPa} \cdot \mathrm{m}^{1 / 2}$ で あり，ほぼ目標值に近い值となった，疲労予き裂部分の応力拡大係数範囲 $\Delta K$ とき裂伝ぱ速度 $d a / d N$ の関係は連 続的であり, 試験後のき裂長さとも良い相関があった. したがって, き裂進展試験後, き裂長さと負荷応力から 算出した応力拡大係数 $27 \mathrm{MPa} \cdot \mathrm{m}^{1 / 2}$ は有効な実験值である.

破壞力学によると，材料は等方・均質の弾塑性体であるという仮定の下でき裂先端の塑性域 $\omega$ は次式で与えら れる(20).

$$
\begin{array}{ll}
\text { 平面応力の場合 } & \omega_{1}=\frac{1}{\pi}\left(\frac{K}{\sigma_{Y}}\right)^{2} \\
\text { 平面ひずみの場合 } & \omega_{2}=\frac{1}{3 \pi}\left(\frac{K}{\sigma_{Y}}\right)^{2}
\end{array}
$$

ここで, $K$ は応力拡大係数, $\sigma_{y}$ は降伏応力である. き裂先端で平面ひずみを満たす条件は次式で与えられる. 
$2.5\left(K / \sigma_{Y}\right)^{2} / B \leqq 1$

ここで，B は試験片板厚である. SUS316L の降伏応力 $\sigma_{y}(276 \mathrm{MPa})$ とCT 試験片の板厚 $(25 \mathrm{~mm})$ を式(4)に代入 すると 0.95 であり，本試験は平面ひずみ条件を満たしている，したがって，平面ひずみ条件の塑性域寸法は式(3) より $\omega_{2}=1.02 \mathrm{~mm}$ であり, 主にこの領域が硬さ分布測定と EBSD 解析の対象となる.

\section{$3 \cdot 2$ 微小硬さ試験によるき裂先端ひずみ分布}

冷間圧延による予ひずみ（真ひずみの換算式 $\varepsilon=\ln \left(A_{0} / A\right), A_{0}$ : 圧延前の断面積, $A$ : 圧延後の断面積）と換算 式から得た微小硬さの関係を図 1 に示す, 微小硬さと真ひずみの関係は, 以下の三次式で最も良く近似できた.

$$
H v^{*}=134.0+843.1 \varepsilon-1692.5 \varepsilon^{2}+1218.7 \varepsilon^{3}
$$

図 2 に, き裂進展試験片のき裂先端の硬さ分布の測定結果を示す. 換算ビッカース硬度 $H v^{*}$ の最低値は 130 (真 ひずみ 0 相当)，最高値は 210 (真ひずみ $10 \%$ 相当）である. 図 2(a) の光学顕微鏡像では粒界が判別できるが, 粒界上と粒内とで，硬さには有意差が無く，必ずしも粒界の影響を評価できていない．図(b)では硬さが高くなっ た青色（H $v^{*}=150 \sim 165 ）$ の領域はき裂先端から進展方向 $200 \mu \mathrm{m} \times 500 \mu \mathrm{m}$ 程度であり，さらにその内側に硬さが 高い橙色 $\left(H v^{*}=165 \sim 180\right)$ の部分があり，き裂先端の直近部では硬さが高くなっている．硬さは不均一の分布を

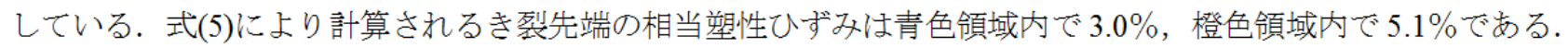
したがって，局所的なひずみの分布が微小硬さに反映されている.

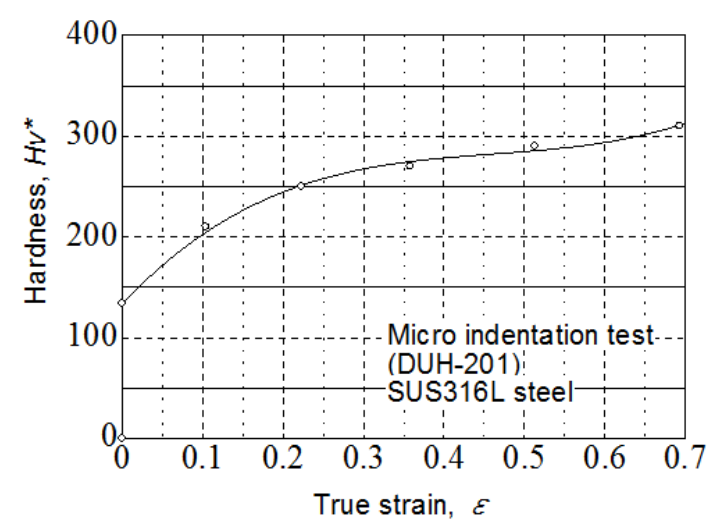

Fig.1 Relationship between Hardness to True strain with the micro indentation tester (DUH-201).

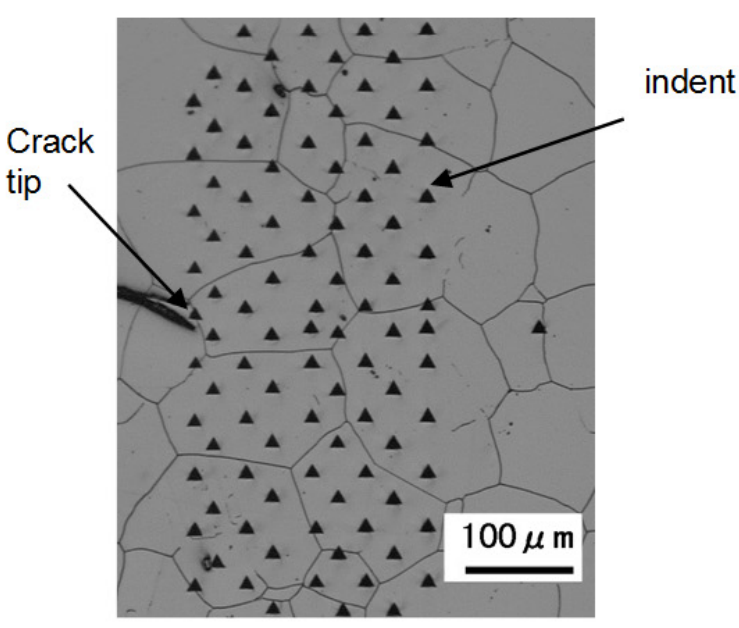

(a) Optical microscope image

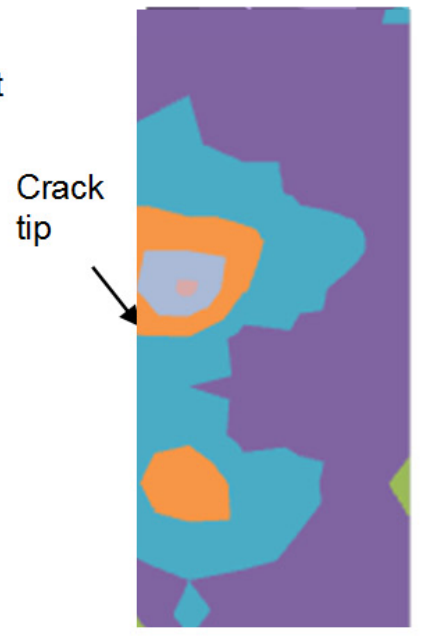

(b) Distribution of the hardness
$195 \cdot 210$

$180 \cdot 195$

$165 \cdot 180$

$150 \cdot 165$

$135 \cdot 150$

$120 \cdot 135$

$100 \mu \mathrm{m}$

Fig.2 A distribution of the hardness with the micro indentation tester (DUH-201). 

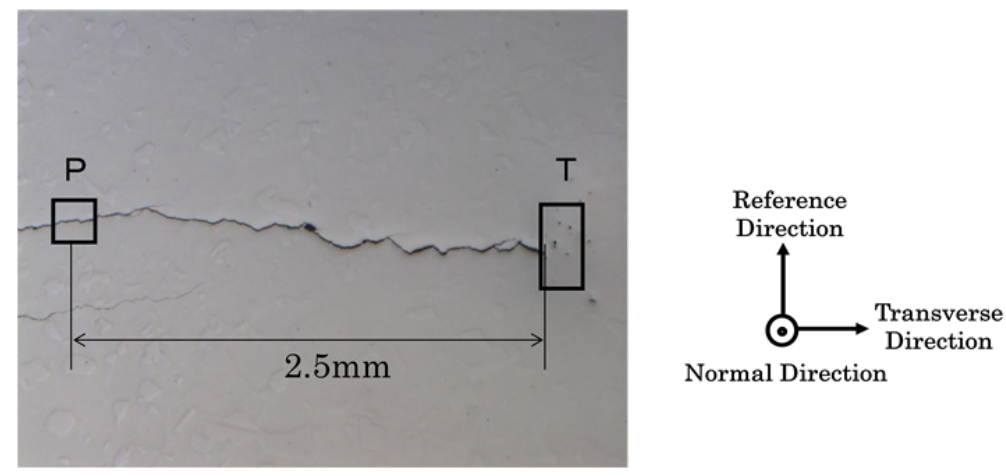

Fig.3 Optical microscope image of SUS316L steel.

\section{$3 \cdot 3$ 方位解析}

図 3 に CT 試験片の中央断面の光学顕微鏡像を示す. EBSD 装置と試料の座標関係は図中に示す通りである. 四角枠 $\mathrm{T}$ はき裂先端であり, 四角枠 $\mathrm{P}$ はき裂先端から $2.5 \mathrm{~mm}$ の位置であり疲労予き裂試験の応力拡大係数範囲 $\Delta K$

$=11 \mathrm{MPa} \cdot \mathrm{m}^{1 / 2}$ に相当する. IQ 值の平均は，(P)領域が 269.33，(T)領域が 279.71 と值が大きく，ともに鮮明 なイメージが観察された．実験方法で述べた通り，IQ map は， kikuchi パターンのバンド強度を反映しておりバ ンドが鮮明であるということは結晶性が優れていることを意味する．したがって，これらの EBSD 像は結晶性が 良く保たれ試料表面のひずみなどが無い状態で取得されている。図 4 に結晶方位分布図を示す。結晶方位は(P) 領域，（T）領域ともにランダムな結晶方位であり, き裂から $100 \mu \mathrm{m}$ 程度離れた結晶の逆極点図にはノイズが含 まれていないことから, 試験前の未変形試料には, サブグレインなどの粒内方位差が全く含まれていない. また, 疲労き裂伝ぱ領域はき裂が蛇行しているが，粒界に関係なく粒内を伝ぱしていることがわかる．図 5 に KAMマ ップを示す.（P）領域はほぼき裂の輪郭に沿って色の濃淡が変化している. 疲労き裂伝ぱ速度から (P) 領域で はき裂が $1.3 \mu \mathrm{m}$ 進むのに約 1000 回の繰り返しを受ける.このため, 繰り返しによる塑性ひずみがき裂に沿って 残っていると考えられる.（T）領域はき裂先端の極近傍に色の濃淡がある. 平面ひずみ条件の塑性域寸法 $\omega_{2}$ は $1.02 \mathrm{~mm}$ であるが $(\mathrm{P})$ 領域と比べても, き裂先端から $1 \mathrm{~mm}$ の範囲に KAM の変化が有るようには見えない.

図 5 の（T）領域は，き裂の極近傍に局所方位差が集中しているように見える．そこで，き裂先端近傍の 100 $\mu \mathrm{m} \times 200 \mu \mathrm{m}$ の範囲に限定して解析した。図 6 に結晶粒界像, 図 7 に KAM マップ, 図 8 に GROD マップを示
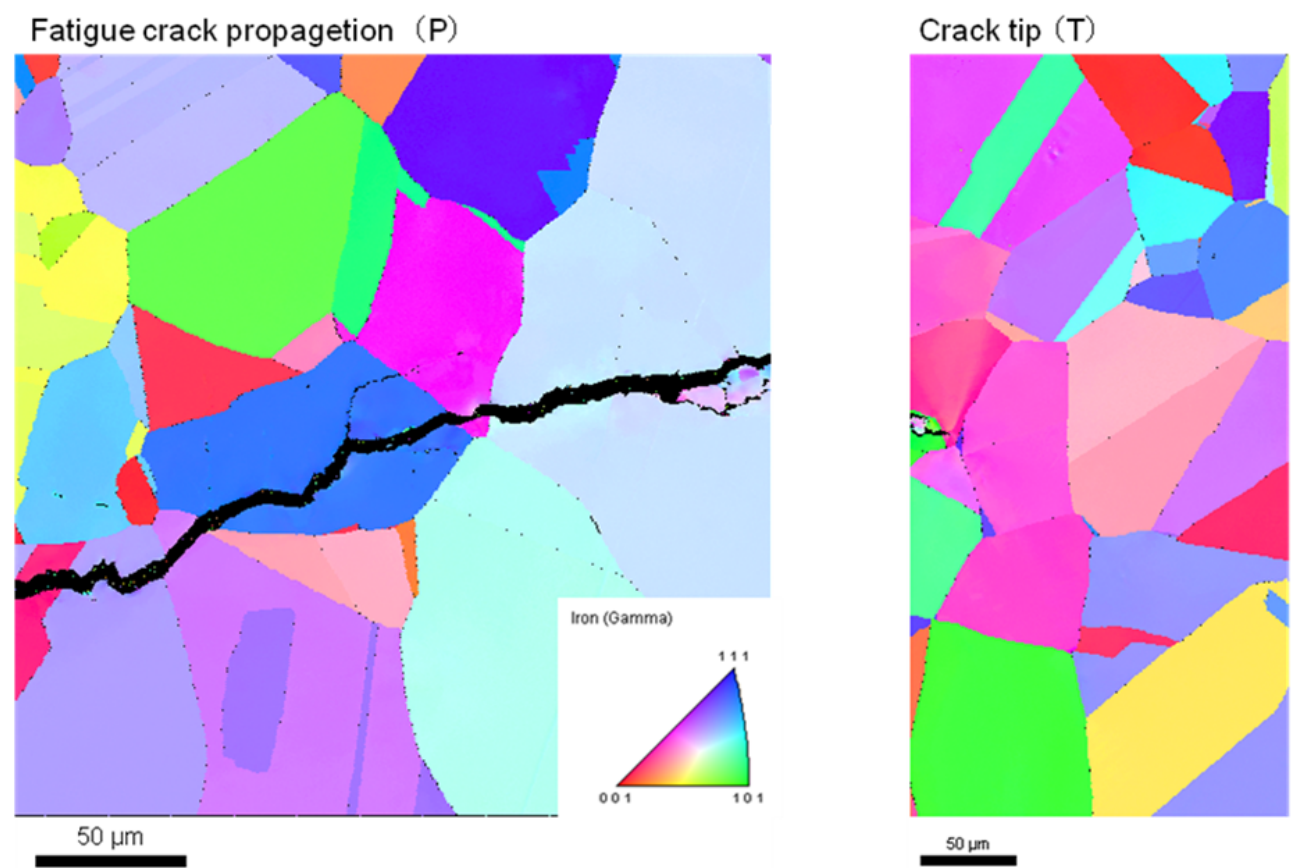

Fig.4 Inverse pole figure map（ND） . 
Fatigue crack propagation $(\mathrm{P})$

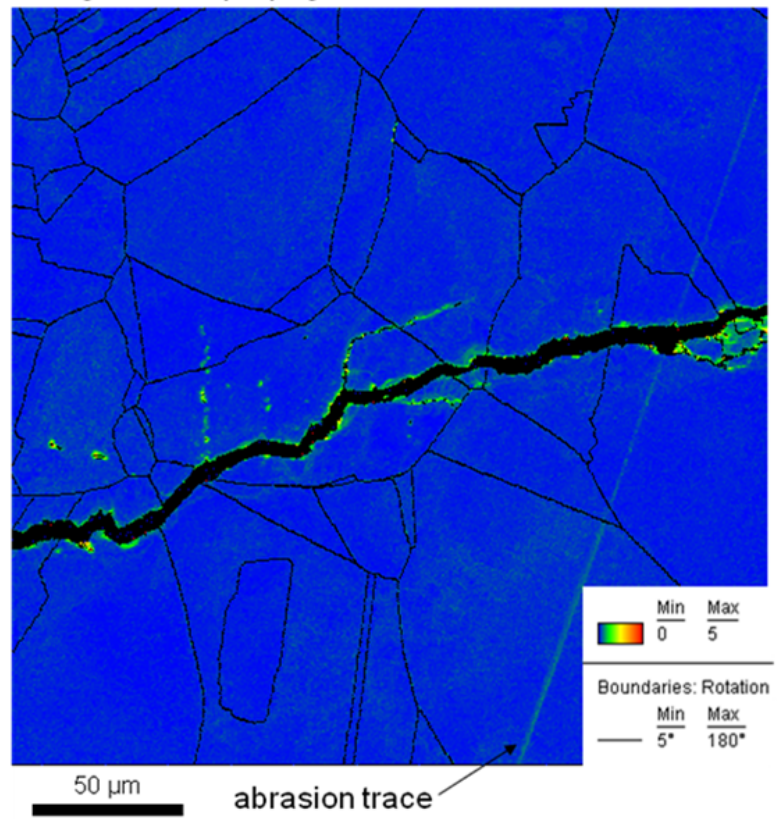

Crack tip (T)

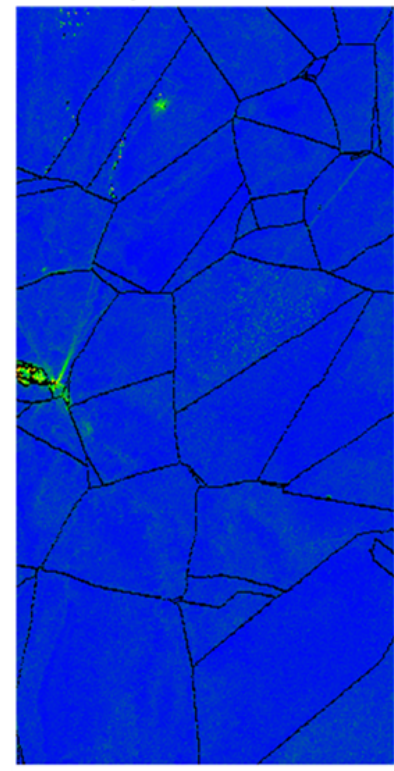

$50 \mathrm{\mu m}$

Fig.5 Kernel average misorientation (KAM) map.

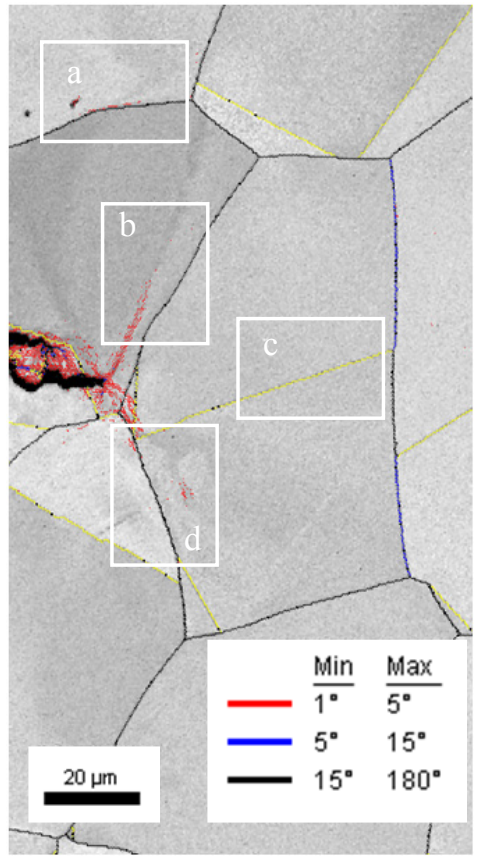

(a) step size $=0.5 \mu \mathrm{m}$

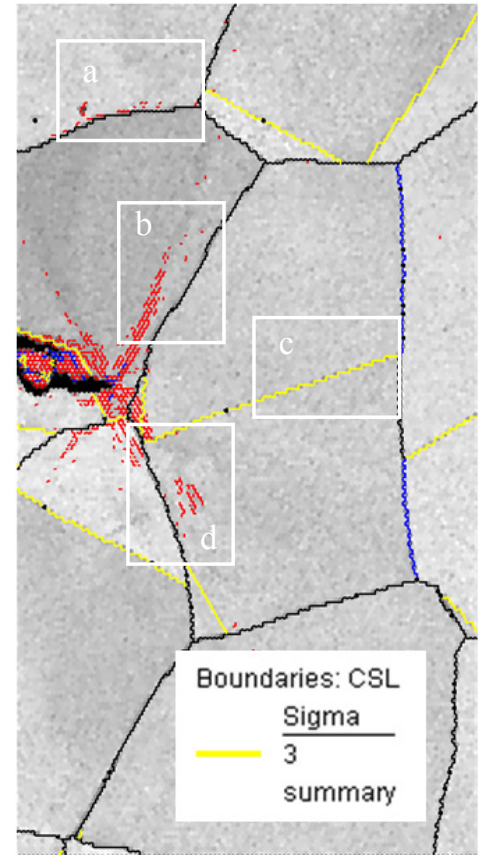

(b) step size $=1.0 \mu \mathrm{m}$

Fig.6 Grain boundary map $(100 \mu \mathrm{m} \times 200 \mu \mathrm{m})$.

し，それぞれ，(a)がステップサイズ $0.5 \mu \mathrm{m}$ のイメージ，(b)がステップサイズ $1.0 \mu \mathrm{m}$ のイメージである. 図 6 の 結晶粒界像では, 赤線が $1^{\circ}$ から $5^{\circ}$ 以下, 青線が $5^{\circ} \sim 15^{\circ}$ 以下, 黒線が $15^{\circ}$ 以上の粒界を示す. 黄色は $\Sigma 3$ CSL 粒界である，図6(b)は(a)に比べて粒界の線が太くなっているが，両像では赤線を除いてほぼ同じ粒界を示してい る. 特にき裂先端の進展方向と一致する粒界は $\Sigma 3$ CSL 粒界であり, き裂先端の約 $60^{\circ}$ 方向に上下に $15^{\circ}$ 以上の ランダム粒界になっている. 図 7 の KAM マップでは, 図 7(a)のステップサイズ $0.5 \mu \mathrm{m}$ に対して, (b)のステップ 


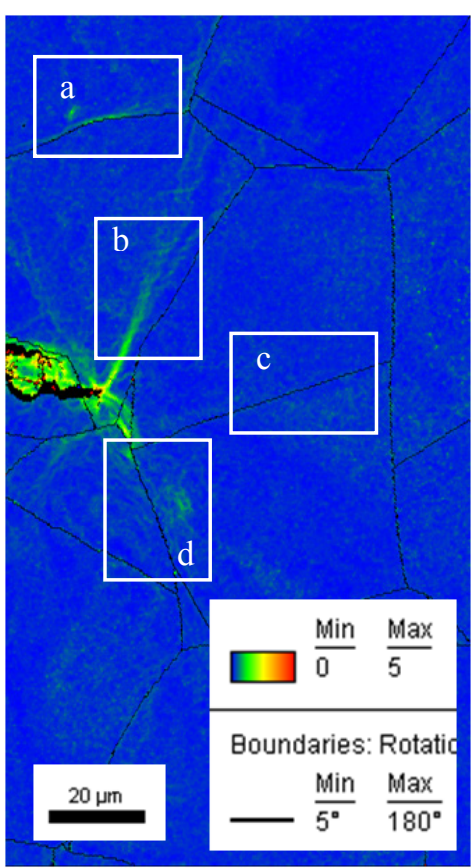

(a) step size $=0.5 \mu \mathrm{m}$

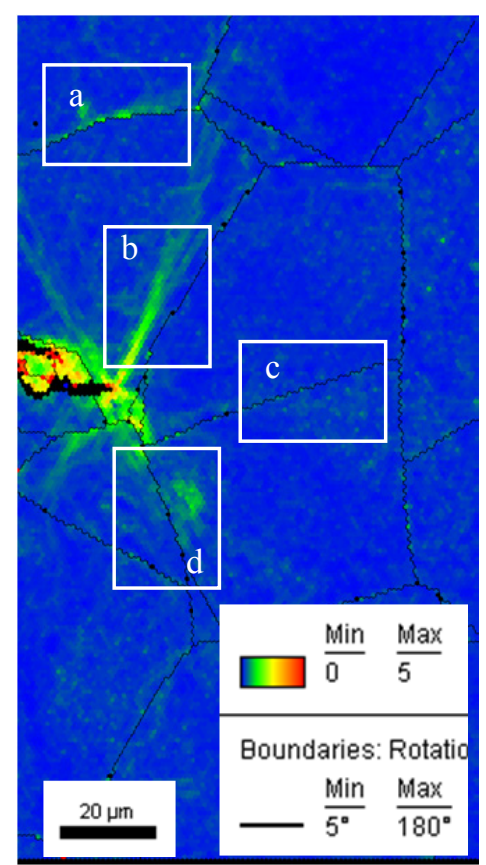

(b) step size $=1.0 \mu \mathrm{m}$

Fig.7 Kernel averagemisorientaion (KAM) map ( $1^{\text {st }}$ nearest neighbor).

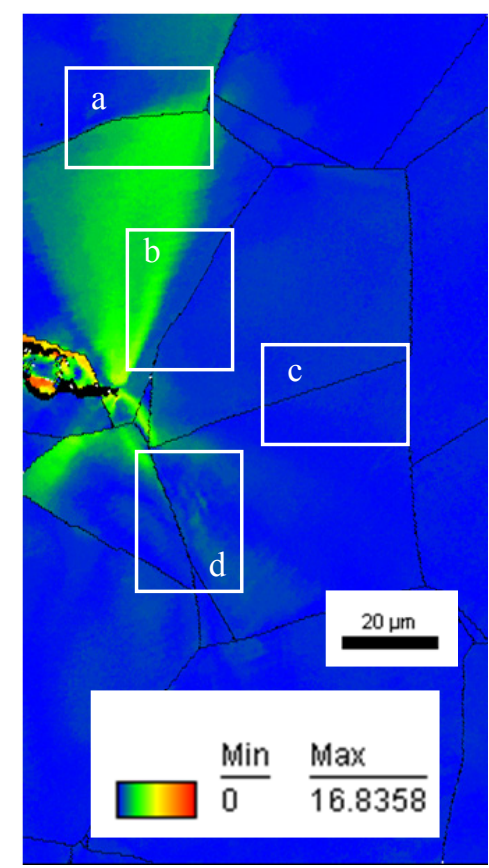

(a) step size $=0.5 \mu \mathrm{m}$

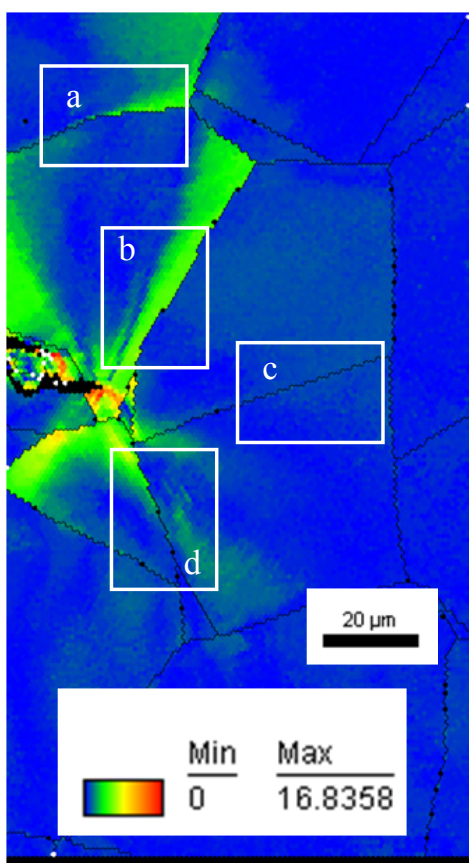

(b) step size $=1.0 \mu \mathrm{m}$

Fig.8 Grain reference orientation deviation (GROD) map .

サイズ $1.0 \mu \mathrm{m}$ の方が局所方位差の分布が広がっている．これは，単位長さ当たりの方位差の変化が一定であっ た場合，理想的には局所方位差はステップサイズに比例して増加することに対応している．他の報告でもステッ プサイズが大きくなると局所方位差の平均值が大きくなる関係が示されている(10) . 両図において, ランダム粒界 近傍の領域 $\mathrm{a}, \mathrm{b}, \mathrm{d}$ は粒界近傍に局所方位差が生じているが， $53 \mathrm{CSL}$ 粒界の領域 $\mathrm{c}$ では局所方位差は生じていな い. しかし，全体の分布傾向は両像でほぼ同じである. 図 8 の GROD マップでは, 図 8(a) と(b)で分布傾向が異な る. 本試料のように, 本来ひずみのない結晶粒内をき裂が進展している場合は, 最小 KAM ピクセルはき裂から 
離れた領域に存在することが多く，最小ピクセル位置とき裂近傍とは比較的大きな結晶方位差を持つため，き裂

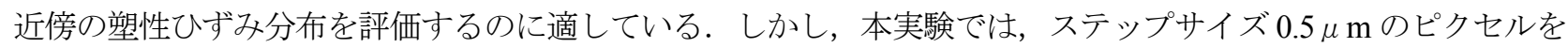
$1.0 \mu \mathrm{m}$ に平均化したことにより, 最小ピクセルの位置が粒内の別の場所に変わってしまったと考えられる.ここ で, GROD がステップサイズの平均化が影響するのであれば，ステップサイズを平均化した図 8(b)が誤りで，平 均化していない図 8(a)が正しい GROD マップである. しかし, 図 8(a)の GROD マップと, 図 7(a)の KAM マップ を比較すると, KAM マップは, 粒界近傍に局所的な方位差が見られるのに対して, GRODマップでは, 粒界に 関係ないカラーマップになっている. Ashby が提案した GN 転位は(5), 結晶粒界の近傍に生ずる変形の不均一性 に伴って粒界近くに存在しなければならない転位という解釈を与えている. Ashbyの GN 転位の概念を取り入れ， 変形の不均一性により粒界近傍に GN 転位が発生したと考えるならば, KAM マップは, 粒界近傍に発生した GN 転位を再現し，GROD は，GN 転位の概念と一致していない。また，大橋は(21)-(23), 多結晶体のすべり変形と転位 の蓄積について, 多結晶体モデルとした計算機シュミレーションを行い, 粒界近傍に GN 転位が蓄積する様子を 再現した. この結果は, 本研究で得られた KAMマップの結果と良く似ている. 現時点では, 変形の不均一性は Ashby の「GN 転位」が支持されていることから, き裂先端の EBSD 解析はGRDO より KAM が適している.

\section{4. 考察}

\section{$4 \cdot 1$ 平面ひずみ状態の塑性ひずみ分布}

微小硬さで得られたき裂先端の硬さ分布（図 2(b)）は，モード I におけるき裂先端での降伏条件を満たしてい る範囲 (Mises 条件) の忘力分布によく似た形状(20)である. 式(5)から推測されるひずみ分布の相当塑性ひずみは, 青い領域が 3.0\%，橙色が 5.1\%であった．ただし，微小硬さ試験では測定間隔，測定精度により，これより小さ な塑性ひずみ分布を表すことができなかった.

一方, EBSD の局所方位解析結果（図 5）のき裂先端ではこの様なひずみ分布に対応する方位差が得られなか った．釜谷は，EBSDによる局所方位差の平均值（mean of the log-normal distribution, $M$ ，この $M$ を modified crystal defomation $(M C D)$ と呼ぶ） と塑性ひずみ量の相関関係を得ている ${ }^{(11)} . S U S 316$ 鋼は $M C D=0.12 \varepsilon_{p}+0.2$ である ${ }^{(11)}$ が，この相関関係は塑性ひずみが 4.9\%〜 $15.0 \%$ の引張試験片から得た経験式であり，塑性ひずみが $0 \%$ も $M C D$ はゼロではない. これは, $0 \%$ の無ひずみ材でも, 局所方位差がゼロにはならずバックグラウンドの方位差が $0.2^{\circ}$ 程度存在するためである。これらのことから, 塑性ひずみが $5 \%$ 以下の場合には, 局所方位差から塑性ひずみを 定量的に評価するのは困難である。このため，微小硬さによるひずみ分布と異なる結果になったと考えられる.

\section{$4 \cdot 2$ き裂先端の不均一変形}

本研究では, 硬さ測定の結果からは, 粒界と粒内に有意差は認められなかった. しかしながら, 図 7 の KAM マップでは，ランダム粒界近傍で不均一な局所方位差が認められた．KAM で見られる局所方位差は四角で囲っ た領域 $\mathrm{a}, \mathrm{b}, \mathrm{d}$ の粒界近傍のみであり, 領域 $\mathrm{a}$ の右側の粒界や, 領域 $\mathrm{d}$ の右側の粒界には局所方位差が生じてい ない.この様な KAM の局所方位差の不均一性は, 粒界近傍に発生した GN 転位を再現し, き裂先端の塑性ひず み分布と相関していると考えられる。

また, 図 7 KAM マップではき裂先端から $20 \mu \mathrm{m}$ しか離れていない領域 $\mathrm{c}$ の粒界で局所方位差は生じていな い.この粒界は $\Sigma 3$ CSL 粒界であった. CSL 粒界は, 粒界エネルギーが低く粒界強度が高く ${ }^{24)}$, 本実験結果は, 平面ひずみ状態の塑性ひずみ領域においてもCSL 粒界で変形が生じにくいことを示唆している.

\section{5. 結論}

低炭素オーステナイトステンレス鋼 SUS316L の厚板 CT 試験片を用い，き裂進展試験を実施し，き裂先端に生 ずる平面ひずみ状態の塑性ひずみ域内のき裂先端の硬さ分布と，方位解析を実施した．得られた結果は以下の通 りである. 
（1）微小硬さ試験による硬さ分布ではき裂先端には $500 \mu \mathrm{m}$ 程度の塑性ひずみ領域が存在し，その領域の相当塑 性ひずみは 3\%と推測された。一方, EBSD解析ではこの様なひずみ分布に対応する方位差が得られなかった。 し たがって，平面ひずみ状態のき裂先端の塑性ひずみ分布は，微小硬さと真ひずみの経験式に基づいて，硬さ分布 を測定することにより可視化できる.

（2）EBSDによる解析は，KAM マップではステップサイズを大きくすると, 局所方位差が大きくなった. 一方, GROD マップでは, ステップサイズが変わると KAM の最小ピクセル位置が別の場所に変わったため, 全く異な る様相となった．したがって，現時点ではき裂先端近傍の局所変形はKAM の解析方が適している.

（3）微小硬さ分布では，粒界と粒内の変形の不均一性を明確にできなかったが，EBSD による KAM マップの解 析結果は，平面ひずみ状態で，き裂先端のランダム粒界で局所的な不均一変形が生じ，き裂先端の CSL 粒界では ほとんど変形が生じないことが明らかとなった.

\section{謝 辞}

本研究は平成 20 年度科学研究費補助金「基礎研究 (c)」課題番号 2056021 の一部として行われた. ここに謝意 を表する.

\section{文献}

（1）日本機械学会編，発電用原子力設備維持規格 JSME NA1-2007, “第 1 部 容器の評価不要欠陥寸法基準”, 解説 3-2-9, 日本機械学会.

（2）北川浩, 小西晴之，中谷彰宏，“結晶構造体に対する計算力学モデルの検討 [ I 結晶すべりモデルを用いる延性き裂 の開口挙動の解析”, 日本機械学会論文集 A 編, Vol. 57, No. 541 (1991), pp. 1986-1991.

（3）中谷彰宏，北川浩，杉崎誠，“離散転位動力学法による繰り返し荷重下のき裂先端近傍メゾ領域に形成される転位 構造と破壊機構の検討”，日本機械学会論文集 A 編, Vol. 65, No. 631 (1999), pp. 575-581.

(4) Kamaya M., Kawamura Y. and Kitamura T., "Three-dimensional local stress analysis on grain boundaries in polycrystalline material", International Journal of Solids and Structures, Vol. 44 (2007), pp. 3267-3277.

(5) Ashby M.F., “The deformation of plastically non-homogeneous materials", Philosophical Magazine, Vol. 21(1970), pp. 399-424.

(6) Wikinson A. J., "A new method for determining small misorientations from electron back scatter diffraction patterns", Scripta Materiala, Vol. 44 (2001), pp. 2379-2385.

(7) 木村英彦, 王, 秋庭義明, 田中啓介, “EBSD 法およびX 線回折法によるステンレス鋼の塑性変形におけるミスオ リエンテーションの解析”，日本機械学会論文集 A 編, Vol. 71, No. 712 (2005), pp. 1722-1728.

（8）釜谷昌幸, “電子後方散乱回折による結晶方位差分布の測定”, 日本機械学会論文集 A 編, Vol. 4, No. 739(2008), pp. 315-322.

（9）佐々木孔英，釜谷昌幸，三浦照光，福谷耕司，“微視的な塑性ひずみ分布と結晶方位差の関係”，日本金属学会誌， Vol. 74, No. 7(2010), pp. 467-474.

(10) Demir E., Raabe D. Zaafarani N. and Zaefferer S., “ Investigation of the indentation size effect through the measurement of the geometrically necessary dislocations beneath small indents of different depths using EBSD tomography”, Acta Materiala, Vol. 57(2009), pp. 559-569.

(11) Kamaya M. Wilkinson A. J. and Titchmarsh J.M., " Quantification of plastic strain of stainless steel and nickel alloy by electron backscatter diffraction”, Acta Materiala, Vol. 54(2006), pp. 539-548.

(12) Kamaya M., "Measurement of local plastic strain distribution of stainless steel by electron backscatter diffraction", Materials Characterization, Vol. 60(2009), pp. 125-132.

(13) Humphreys F. J., " Review Grain and subgrain characterization by electron backscatter diffraction”, Journal of Materials Science, Vol. 36(2001), pp. 3833-3854.

(14) 松岡三郎, “低炭素オーステナイト系ステンレス鋼 SUS316 の加工硬化材における $0.2 \%$ 耐力とビッカース硬さの 関係”，日本機械学会論文集 A 編, Vol. 70, No. 698(2004), pp. 1535-1541.

(15) 宮原健介, 長島伸夫, 松岡三郎，大村孝仁，“超微小押し込み試験によるビッカース硬さ值の評価”，日本機械学会 論文集 A 編, Vol. 64, No. 626(1998), pp. 2567-2573. 
(16) 長島伸夫, 宮原健介, 松岡三郎, “高強度鋼中の介在物の AFM 超微小硬さ試験“, 日本機械学会論文集 A 編, Vol.65, No.631(1999), pp. 477-482

(17) Miyahara K., Nagashima N. and Matsuoka S., " Development and application of a combined atomic force microscopy-nanoindentation system with a silicon tip and a diamond indenter", Philosophical Magazine A, Vol. 82, No. 10(2002), pp. 2149-2160.

(18) Nagashima N. and Matsuoka S., " Nanoscopic strength analysis of work-hardened L-grade austenitic stainless steel,316(NG)”, Materials Transactions, Vol. 47, No. 9(2006), pp. 2326-2334.

(19) 長島伸夫, 早川正夫, 塚田 隆, 加治芳行, 三輪幸夫, 安藤昌視, 仲田清智, “低炭素オーステナイト系ステンレ 又鋼 SUS316L の粒内・粒界の変形挙動の評価”，圧力技術，Vol. 47, No. 4(2009), pp. 236-244.

（20）小林英男，「破壊力学」共立出版(1993), pp. 90-100.

(21) Ohashi T., “Three-dimensional structures of the geometrically necessary dislocations generated from non-uniformities in metal microstructures", Proc. IUTAM symp. on Multiscale modeling and characterization of elastic-inelastic behavior of engineering materials, Marrakech, (2002), pp. 183-190.

(22) Ohashi T., " A new model of scale dependent crystal plasticity analysis”, Proc. IUTAM symp. on Mesoscopic dynamics of fracture process and materials strength, OSAKA, (2003), pp. 97-106.

（23）大橋鉄也，日本鉄鋼劦会第 180 回 西山記念技術講座 (2004），pp. 75-95.

(24) 堀内寿晃, 石橋良, 山本道好, 国谷治郎, 連川貞弘, 粉川博之, 渡邊忠雄, 庄子哲雄, “粒界性格制御 SUS304 鋼 の粒界型応力腐食割れ発生・進展性”，第 52 回材料と環境討論会 (2005), B-305. 